\title{
Super absorbent polymer application in seeds and planting furrow: it will be a new opportunity for rainfed agriculture
}

\section{Polímero superabsorvente em sementes e no sulco de plantio: uma nova oportunidade para agricultura de sequeiro}

\author{
Angélica Fátima de Barros $^{1 *}$; Leonardo Duarte Pimentel2; Eduardo Fontes Araujo ${ }^{2}$; \\ Leandro Roberto de Macedo ${ }^{3}$; Hermínia Emília Prieto Martinez²; \\ Vanessa Aparecida Pereira Batista ${ }^{4}$, Mateus Queiroz da Paixão ${ }^{5}$
}

\begin{abstract}
Brazil is the fourth largest grain producer in the world. Its agriculture is mainly rainfed, with two cropping seasons per year. While the first crop (i.e., spring/summer) receives greater precipitation, the second crop (i.e., autumn/winter) is associated with greater risk of crop failure mainly due to the low rainfall, suggesting that technologies that could optimize water use during that period are needed. Superabsorbent polymers (SAP) are used in the forestry sector to reduce seedling mortality and the frequency of irrigation of eucalyptus and pinus glue owing to their ability to increase water storage capacity in the soil. However, to our knowledge, very little is known about the use of SAP in annual agricultural crops. To this end, the effects of SAP, as a seed coat or applied in the planting grooves, on the initial development of sorghum seedlings under conditions of water deficit were evaluated in two experiments under greenhouse conditions. In experiment 1 , sorghum seeds with and without SAP coating were seeded in trays and subjected to three irrigation intervals to induce water deficit. The percentage of emergence and emergence speed index were evaluated and, at 26 days after sowing, seedling height, number of leaves per plant, survival rate, and dry mass of shoot and root were evaluated. In experiment 2, the seeds of sorghum with and without SAP coating were sown in pots, with SAP applied in the planting grooves. At 30 days after sowing, the plant stand, number of leaves per plant, plant height, and dry matter mass of leaves, stem, and root were evaluated. The results showed that SAP applied both as a seed coat and in planting grooves increased seedling growth and dry mass of aerial parts at 26 days and 30 days for experiments 1 and 2, respectively. In addition, seed coating with SAP increased plant survival rate, but reduced the rate of seedling emergence in both experiments. Therefore, the use of SAP as a seed coat or applied in the planting groove has beneficial effects on the vegetative development of sorghum under low water conditions. Further research is needed to address the effect of SAP on seedling emergence.

Key words: Water deficit. Hydrogel. Seed coat. Sorghum bicolor L. Moench.
\end{abstract}

${ }^{1}$ Discente de Doutorado em Fitotecnia, Universidade Federal de Viçosa, UFV, Viçosa, MG, Brasil. E-mail: angelica.barros@ufv.br

${ }^{2}$ Profs. Drs., Departamento de Fitotecnia, UFV, Viçosa, MG, Brasil. E-mail: leonardo.pimentel@ufv.br; efaraujo@ufv.br; herminia@ufv.br

3 Prof. Dr., Departamento de Economia, Universidade Federal de Juiz de Fora, Campus de Governador Valadares, UFJF/GV, Governador Valadares, MG, Brasil. E-mail: leandro.macedo@ufjf.edu.br

${ }^{4}$ Discente de doutorado em Produção Vegetal, Universidade Estadual do Norte Fluminense Darcy Ribeiro, UENF, Campos dos Goytacazes, RJ, Brasil

${ }^{5}$ Eng $^{\circ}$ Agr $^{\circ}$, UFV, Viçosa, MG, Brasil. E-mail: agro.mateusqueiroz@gmail.com

* Author for correspondence 


\section{Resumo}

O Brasil é o quarto maior produtor de grãos no mundo. Sua agricultura é baseada em cultivos de sequeiro, com duas safras por ano. A segunda safra é a mais afetada, por estar associada à maiores riscos climáticos, principalmente pela baixa pluviosidade nos meses de janeiro à abril. Nesse sentido, tecnologias que otimizem o uso da água podem reduzir os riscos de quebra de safra. O uso de polímeros superabsorventes (PSA) vem sendo consolidado no setor florestal, visando reduzir a mortalidade de mudas e a frequência de irrigações de pegamento de eucalipto e pinus devido ao aumento da capacidade de armazenamento de água no solo. Entretanto, não há relatos sobre o uso do PSA em culturas anuais. $\mathrm{O}$ objetivo deste trabalho foi avaliar o efeito do PSA como revestimento de sementes e no sulco de plantio no desenvolvimento inicial de plântulas de sorgo sob condições de déficit hídrico. Foram conduzidos dois experimentos em casa de vegetação. No experimento 1, sementes de sorgo com e sem revestimento com PSA foram semeadas em bandejas e submetidas a três intervalos de irrigação para induzir déficit hídrico nas plântulas. Avaliou-se a porcentagem de emergência e o índice de velocidade de emergência e, aos 26 dias após a semeadura, foram avaliadas a altura de plântulas, número de folhas por planta, taxa de sobrevivência e massa seca da parte aérea e da raiz. No experimento 2 foram semeadas em vasos sementes de sorgo com e sem revestimento com PSA e também a aplicação do PSA no sulco de plantio, a fim de avaliar o uso e o método de aplicação do PSA. Aos 30 dias após a semeadura avaliouse o estande de plantas, número de folhas por planta, altura de plantas e massa de matéria seca das folhas, do colmo e da raiz. Observou-se que o uso do PSA aplicado tanto via revestimento como no sulco de plantio, contribuiu para que as plântulas tivessem maior crescimento e massa seca de parte aérea. Além disso, as plântulas cujas sementes foram revestidas com PSA apresentaram maior taxa de sobrevivência. Entretanto, em ambos os experimentos, as plântulas oriundas das sementes revestidas com PSA apresentaram menor índice de emergência. Logo, o uso do PSA no revestimento de sementes e no sulco de plantio apresenta efeitos benéficos no desenvolvimento vegetativo do sorgo sob déficit hídrico. Contudo, os problemas relacionados à emergência precisam ser resolvidos para viabilizar a utilização do produto.

Palavras-chave: Déficit hídrico. Hidrogel. Revestimento de sementes. Sorghum bicolor L. Moench.

\section{Introduction}

The world's demand for food, fiber, and bioenergy is projected to increase in the coming decades, as a result of the increase in the world population and improvement of the purchasing power in emerging countries (GILBERT, 2010). On the other hand, these projections are confronted with forecasts of possible global warming, with risks of loss of agricultural areas due to desertification, and increases in extreme climatic events such as prolonged droughts (STRECK; ALBERTO, 2006). This potentially presents a huge challenge for mankind, especially regarding food production, because water is the main component of living organisms and is a major limiting resource for crop production (MUELLER et al., 2012).

Brazil is the fourth largest grain producer in the world (USDA, 2016). Approximately 96\% of this production is not irrigated and depend only on the rainfalls (PAULINO et al., 2011). In addition, in the main grain-producing regions, two crops are common: one in the spring/summer (receiving greater precipitation), and the other in autumn/winter (receiving less precipitation) when production is more affected by low water conditions. Typically, the autumn/winter cropping season is associated with lower rainfall volume and longer intervals between precipitation, low temperatures (i.e. frost), reduction of both solar radiation and day's length, thereby presenting greater risks to producers. In this season, crop failure is often mainly due to low precipitation during the seedling emergence and crop establishment phase (BORGHI et al., 2014).

Strategies that enhance water retention in soil, and thus minimize the risk of crop failure at the establishment phase, include no-tillage farming, terracing and level cultivation. In addition, replacing crop varieties or species with higher water demand 
such as maize (Zea mays L.) with those with a relatively low water demand such as sorghum (Sorghum bicolor L. Moench) are potential solutions in regions with higher probability of rainfall deficit. Nonetheless, these strategies do not guarantee satisfactory emergence and initial development of seedlings in case of water deficit, because there are environmental and genetic limits under low water soil conditions. Therefore, novel technologies that optimize water use efficiency at the seedling development phase of rainfed crops are needed. In the forestry sector, SAP has been used to minimize water stress in the planting of eucalyptus and Pinus seedlings (ORIKIRIZA et al., 2013). Moreover, in Brazil, SAP is widely used in winter plantings to reduce seedling mortality and the frequency of glue irrigations.

SAPs, also known as hydrogels, are hygroscopic materials composed of acrylamide monomers (acrylic acid and sodium or potassium acrylate). The carboxyl group along the polymer chain confers high water absorption capacity, although the cross-links present in the chain avoid its complete solubilization (BORTOLIN et al., 2012). In agriculture, polyacrylamide is the main synthetic polymer used, and it absorbs water through the formation of hydrogen bonds (AHMED, 2015). SAP can absorb water up to 200-400 times its weight and increase its size by up to 100 times. The end products of SAP degradation in soil are carbon dioxide, water, and ammonia (WALLACE, 1986). Nevertheless, there is limited understanding about the degradation of SAP in soil and whether, for example, there is a risk of soil acidification. SAPs can remain in soil up to 5 years (SAAD et al., 2009).

The main benefit of using SAP is related to the maintenance of soil moisture, because it can double the storage capacity of water in soil, or improve soil aeration and electrical conductivity (MENDONÇA et al., 2013). According to Nimah et al. (1983), SAP increases water retention by $25 \%$ and $25-30 \%$ in sandy soil and clay soil, respectively. Indeed, the effect of SAP has been studied in different cropping systems, and it is known that SAP increases crop productivity by increasing plant biomass (shoot and root biomass) and improving nutrient absorption by crop roots, thereby reducing nutrient losses through leaching (BERNARDI et al., 2012; NAVROSKI et al., 2015). In addition, Dranski et al. (2013), Fagundes et al. (2014), and Vale et al. (2006) found that SAP used as a soil conditioner increased the survival rate of sapwood, citrus and coffee seedlings under rainfall and/or reduced supplementary irrigation.

To date, as discussed above, SAP has mainly been used as a soil conditioner, i.e., the product is mixed in soil to increase water retention and reduce the need for supplementary irrigation in perennial plants. Very less is known about the use of SAP in annual crops, likely because of the large tracts in cultivated land under annual crops, which would require large volumes of SAP input. However, if the product was applied as a seed coat, a small quantity would be required and the technology could optimize the initial development of the seedlings by improving seed hydration under conditions of water deficit. Thus, SAP applied via seed coating in annual crops could reduce the risks of crop failure in rainfed agriculture, with this resulting in increased agricultural production.

The objective of this work was to evaluate the potential of using SAP as a seed coat in sorghum, and to compare the efficiency of the application methods (i.e., SAP applied as a seed coat or in planting grooves). Sorghum was chosen as a model plant in this work because of its greater tolerance to low water soil conditions among the major cereal crops.

\section{Material and Methods}

Two experiments were conducted in a greenhouse. In Experiment 1, sorghum seeds were sown in trays on January 9, 2015, and final evaluations (discussed below in this section) were done after 26 days. In Experiment 2, sorghum was sown in pots on March 2 , and the evaluations were done after 30 days. The environmental conditions for both experiments are described in Figure 1. 
The seed coating was performed in the laboratory, one day before sowing. With the aid of tweezers, the seeds were moistened with $20 \%$ (v/v) polyvinyl acetate-based adhesive (Cascorez extra ${ }^{\circledR}$ ) to adhere the SAP to the seeds. The SAP used was the commercial product Agrogel ${ }^{\circledR}$. For this, the amount of SAP to be applied to 100 seeds was placed on a Petri dish, and the seeds were coated manually with the aid of forceps. The estimated amount of SAP for seed coating, for a stand of 120,000 plants at $91 \%$ seed germination rate, was $7 \mathrm{~kg} / \mathrm{ha}$. Commercial seeds of forage sorghum, variety BRS 655 , with germination of $91 \%$ and moisture level of $12 \%$, determined before the experiment was set up, were used according to the Rules for Seed Analysis (BRASIL, 2009).

Figure 1. Daily mean of the relative air humidity, average maximum temperature and mean minimum daily temperature of the greenhouse during the conduction period of the experiments: A) Experiment 1: 09/01/2015 to day 04/02/2015; B) Experiment 2: 02/03/2015 to day 02/04/2015.

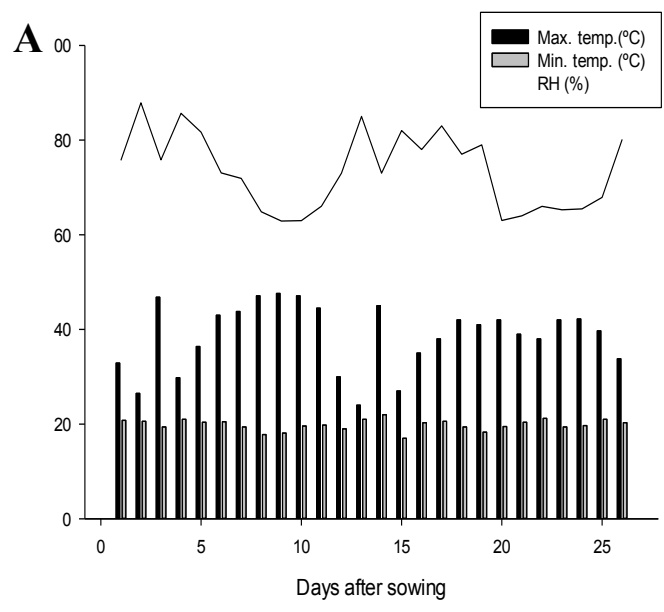

\section{Experimental design}

Experiment 1 -A completely randomized design was used in a $2 \times 3$ factorial scheme, with two types of seed coating (with and without SAP coating) and three intervals between irrigations (48, 72 and 96 hours). These were replicated four times, totaling 24 experimental units. Each experimental unit consisted of a tray containing 100 seeds. Sorghum seeds were distributed in 4 grooves (25 seeds/ groove) spaced $6 \mathrm{~cm}$ apart and to a depth of $4 \mathrm{~cm}$. The plastic trays had holes about $1 \mathrm{~cm}$ in diameter at the bottom to allow drainage. As a substrate, the mixture was mixed with $60 \%$ soil, $30 \%$ sand and 10\% commercial Plantimax ${ }^{\circledR}$ substrate (Table 1). All irrigations were performed in order to raise the moisture of the substrate to the field capacity, determined by measuring the water leaving the bottom of the tray.

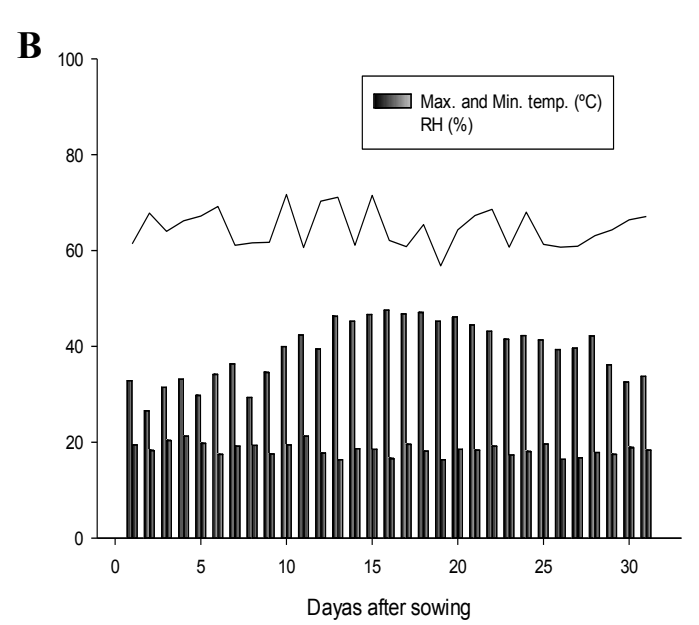

Experiment 2 - Here, the first factor was the three methods of application of SAP (without SAP or control, seeds coated with SAP and SAP applied in the planting groove). The second factor consisted of four intervals between irrigations (48, 72, 96 and 120 hours), with four replications, totaling 48 experimental units. The sowing was done in plastic vessels $(5 \mathrm{~L})$. Three grooves spaced at 12 $\mathrm{cm}$ apart were used, forming an equilateral triangle where the seeds were placed in each vertex. Each experimental unit was composed by a pot with 3 sorghum seedlings. For fertilizer application, $5 \mathrm{~g}$ of 8:28:16 (NPK) were placed per pot to a depth of 5 $\mathrm{cm}$, and 2 seeds/furrow (total of 6 seeds/pot) were distributed to a depth of $3 \mathrm{~cm}$. In treatments with SAP placed in planting groove, an amount of $3 \mathrm{~g}$ of SAP was applied together with the fertilizer. At 15 days after sowing the thinning was performed, leaving 3 seedlings per pot. 
Table 1. Physical-chemical analysis of the substrate used in experiments 1 and 2.

\begin{tabular}{|c|c|c|c|c|c|c|c|c|c|}
\hline & \multirow{2}{*}{$\begin{array}{c}\mathrm{pH} \\
\left(\mathbf{H}_{2} \mathbf{0}\right)\end{array}$} & \multirow{2}{*}{\multicolumn{2}{|c|}{$P_{\mathrm{mg} / \mathrm{dm} 3^{K}}$}} & $\mathrm{Ca}^{2+}$ & $\mathbf{M g}^{2+}$ & $\mathbf{A l}^{3+}$ & SEB & ECEC & CEC \\
\hline & & & & \multicolumn{6}{|c|}{$\mathrm{Cmol}_{\mathrm{c}} / \mathrm{dm}^{3}$} \\
\hline & 5.16 & 21.6 & 104 & 2.9 & 1.28 & 0 & 4.45 & 4.45 & 6.95 \\
\hline \multirow[t]{6}{*}{ Exp. 1} & BSI & ASI & $\mathbf{O M}$ & & Clay & Silt & Sand & & \\
\hline & $\%$ & & $\mathrm{dag} / \mathrm{Kg}$ & $\mathrm{mg} / \mathrm{dm}^{3}$ & & $\mathrm{Kg} / \mathrm{Kg}$ & & & \\
\hline & 64 & 0 & 1.75 & 15.6 & 0.439 & 0.002 & 0.559 & & \\
\hline & pH & $\mathbf{P}$ & $\mathbf{K}$ & $\mathrm{Ca}^{2+}$ & $\mathbf{M g}^{2+}$ & $\mathrm{Al}^{3+}$ & SEB & ECEC & CEC \\
\hline & $\left(\mathbf{H}_{2} \mathbf{0}\right)$ & \multicolumn{2}{|c|}{$\mathrm{mg} / \mathrm{dm}^{3}$} & & & $\mathrm{Cmol}_{c} /$ & $\mathbf{d m}^{3}$ & & \\
\hline & 5.93 & 18.9 & 150 & 3.02 & 0.46 & 0 & 3.86 & 3.86 & 4.56 \\
\hline \multirow[t]{3}{*}{ Exp. 2} & BSI & ASI & OM & $\mathbf{P}_{\text {rem }}$ & Clay & Silt & Sand & & \\
\hline & $\%$ & & $\mathrm{dag} / \mathrm{Kg}$ & $\mathrm{mg} / \mathrm{dm}^{3}$ & & $\mathrm{Kg} / \mathrm{Kg}$ & & & \\
\hline & 84.6 & 0 & 0.4 & 20 & 0.298 & 0.006 & 0.695 & & \\
\hline
\end{tabular}

$\mathrm{P}-\mathrm{K}-$ Mehlich Extractor $1 \mathrm{P}-\mathrm{rem}=$ Remnant Phosphorus

$\mathrm{Ca}-\mathrm{Mg}-\mathrm{Al}-$ Extractor: $\mathrm{KCl}-1$ mol/L Organic Matter (OM) - Oxidation: $\mathrm{Na}_{2} \mathrm{Cr}_{2} \mathrm{O}_{7} 4 \mathrm{~N}+\mathrm{H}_{2} \mathrm{SO}_{4} 10 \mathrm{~N}$

$\mathrm{H}+\mathrm{Al}-\mathrm{Calcium}$ Acetate Extractor $0.5 \mathrm{~mol} / \mathrm{L}-\mathrm{pH} 7.0 \mathrm{ASI}=$ Aluminum Saturation Index

$\mathrm{SEB}=$ Sum of Exchangeable Bases BSI $=$ Basis Saturation Index

ECEC ( $(t)$ - Effective Cation Exchange Capacity CEC (T) - Cation Exchange Capacity pH 7.0.

\section{Assessments}

Experiment 1 - The percentage of emergence (E) and emergence speed index (ESI), obtained by daily counting of the number of seedlings with the visible coleoptile loop, were evaluated. At 26 days after sowing, the rate of emergence was calculated according to the formula described by Maguire (1962) and the following evaluations: 1) height of seedlings $(\mathrm{cm})$, measured from surface of soil to the last fully expanded leaf; 2) average number of leaves, counted in a random sample of 10 plants per experimental unit; 3) survival rate $(\%)$, calculated as the ratio of the number of live seedlings at the end of the experiment to the total number of seedlings emerged. Subsequently, roots of 10 randomly selected seedlings per experimental unit were washed, and plants were separated in root and aerial parts, packed in craft paper, and dried in a forced circulation oven at $65{ }^{\circ} \mathrm{C}$ for 72 hours. Thereafter, the plant fractions were weighed on an analytical balance to determine: 4) dry mass root (DMR); 5) dry mass shoot (DMS).

Experiment 2 - At 30 days after sowing the following were evaluated: 1) number of live plants (stand); 2) number of leaves per plant; 3) Height of plants $(\mathrm{cm})$, measured with ruler graduated in millimeters from the soil surface to the apex of the plant. Afterwards, the roots of all plants were washed, sectioned in root and aerial parts, conditioned on craft paper, and taken to dry in a forced circulation oven at $65^{\circ} \mathrm{C}$ for 72 hours. The harvested plant parts were also weighed in the laboratory to determine: 4) leaf dry mass; 5) stem dry mass.

Statistical analyses were performed using the F-test analysis of variance at 5\% level of probability and the Turkey's test of means at 5\% level of significance. All statistical analyses were performed using the free software R version 3.1.2 (2014).

\section{Results and Discussion}

In Experiment 1, significant effects of the SAP $(\mathrm{P}<0.05)$ on seedling emergence percentage of emergence (E), emergence speed index (ESI), seedling height and mass of shoot dry matter were observed (Figure 1). There was no significant effect of SAP coating $(\mathrm{P}<0.05)$ on the number of leaves, seedling survival rate, and mass of root dry matter. For the interval between irrigations, all measured variables were significantly affected, with the exception of ESI $(\mathrm{P}>0.05)$. There was also 
a significant interaction effect of SAP and irrigation interval on seedling emergence (E). Between the irrigation intervals, higher seedling survival rates were observed in irrigation intervals 1 (48h) and 2 (72h) (Table 2). However, for irrigation interval 3 (96h), lower vegetative performance and seedling survival rate were observed, indicating that the longer irrigation interval limited the growth and development of sorghum seedlings (Figures 2 and 3). Likewise, in Experiment 2, the longer irrigation interval caused a progressive reduction in height and dry matter mass of the stems and leaves (Figure 4). This suggests that the longer interval of irrigation induced water deficit in both experiments. In situations of reduced soil water availability, the plant physiological responses include decreased leaf area production, stomata closure, accelerated leaf senescence and abscission (TAIZ and ZEIGER, 2013), as strategies to optimize water use thereby increasing chances of survival.

Table 2. Comparison of means between emergence speed index (ESI), seedling height (SH), leaf number (LN), survival rate (SR) dry mass root (DMR) and shoot (DMS) in sorghum seedlings at 26 days as a function of three irrigation intervals.

\begin{tabular}{lcccccc}
\hline Treatment & ESI & SH $(\mathrm{cm})$ & LN & SR $(\%)$ & DMR $(\mathrm{g})$ & DMS $(\mathrm{g})$ \\
\hline Irrigation 1 & $13.54 \mathrm{a}$ & $26.00 \mathrm{a}$ & $4.12 \mathrm{a}$ & $100 \mathrm{a}$ & $1.13 \mathrm{a}$ & $0.17 \mathrm{a}$ \\
Irrigation 2 & $13.61 \mathrm{a}$ & $22.98 \mathrm{a}$ & $4.25 \mathrm{a}$ & $100 \mathrm{a}$ & $0.68 \mathrm{a}$ & $0.14 \mathrm{a}$ \\
Irrigation 3 & $14.41 \mathrm{a}$ & $15.75 \mathrm{~b}$ & $3.43 \mathrm{~b}$ & $53.09 \mathrm{~b}$ & $0.42 \mathrm{~b}$ & $0.06 \mathrm{~b}$ \\
\hline
\end{tabular}

Means followed by the same letter in the column do not differ by Tukey's test at the $5 \%$ probability level.

Irrigation 1: interval between irrigations of 48 hours; Irrigation 2: interval between irrigations of 72 hours; Irrigation 3: 96 hours.

In experiment 1 , seed coating with SAP increased $\mathrm{SH}, \mathrm{LN}, \mathrm{SR}$, and DMS by $39 \%, 13 \%, 15 \%$, and $113 \%$ respectively (Table 3 ), and greater effects were observed when SAP coating was combined with irrigation interval 3 (i.e. the most limiting irrigation interval). Here, the SAP used as a seed coat combined with irrigation interval 3 increased $\mathrm{SH}$, LN, SR and DMS by $100 \%, 33 \% ; 66 \%$ and $300 \%$, respectively. However, we note that the increase in seedling vegetative development observed here may not be exclusively attributed to SAP coating, in considering that SAP coating resulted in a smaller number of seedling emergence and consequently less water competition between plants.

In Experiment 2, SAP application only significantly affected number of plants (NP) $(\mathrm{P}<0.05)$, while irrigation interval significantly affected plant height, leaf dry mass and stem dry mass. There was also a significant interaction effect of SAP application method and irrigation interval on number of leaves per plant. The beneficial effect of SAP on vegetative development can be explained by the improvement in water retention in soil and the reduction of nutrient leaching, resulting in optimum use of irrigation water (MARQUES et al., 2010; BORTOLIN et al., 2012). In addition, the polymer works similarly to the mucilage produced by the roots, protecting them against desiccation under conditions of severe water deficit (LIU et al., 2013). Others have reported similar effects in seedlings. For example, Fagundes et al. (2014) observed the beneficial effect of SAP application on the development of saplings planted under water stress. 
Figure 2. Sorghum seedlings at 8,16 and 26 days after sowing (DAS) as a function of superabsorbent polymer (SAP) coating and intervals between irrigations (48, 72 and 96 hours).
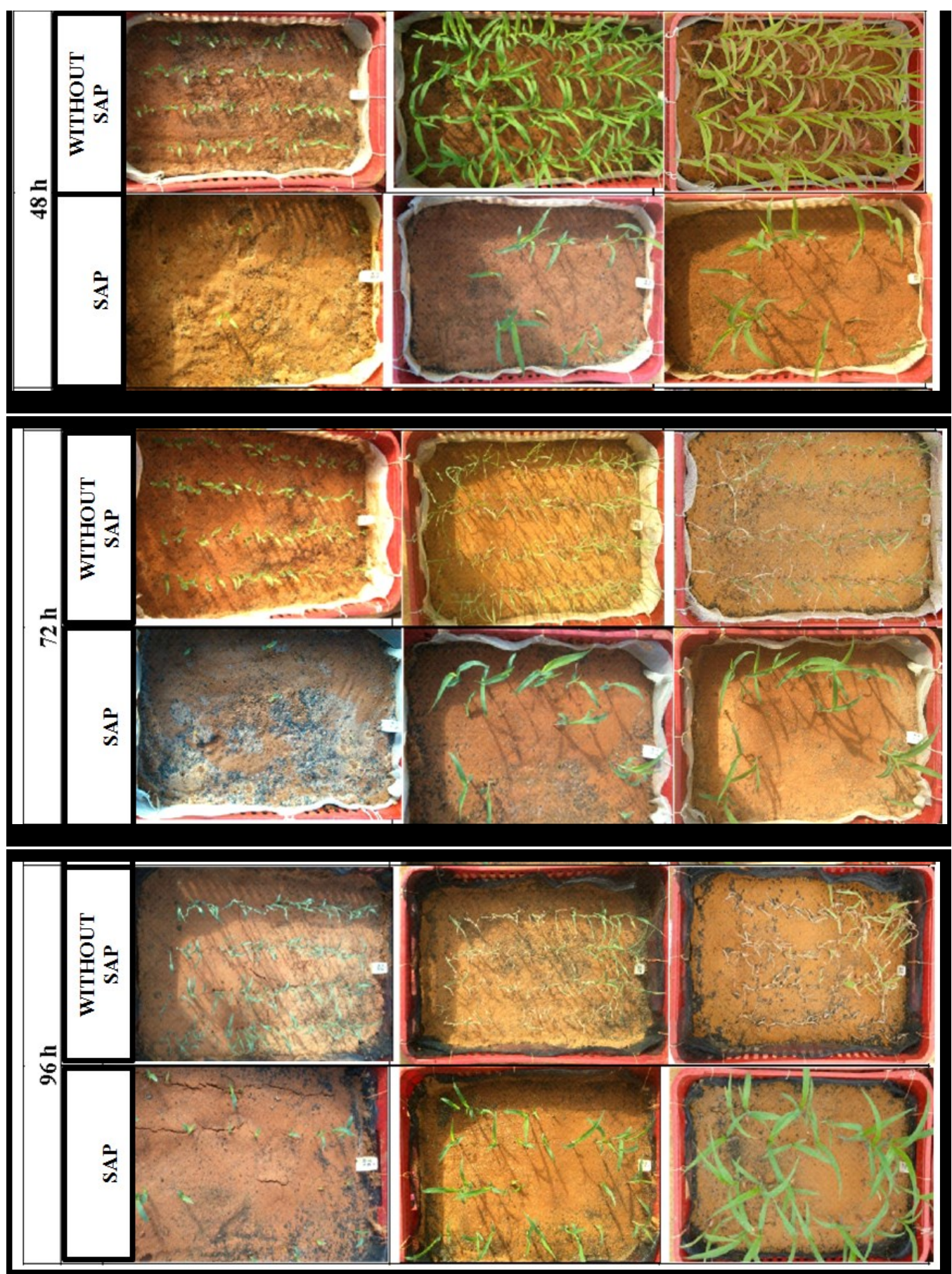
Figura 3. Effect of SAP use on seed coat: A) percentage of emergence; B) emergency speed index; C) seedling height; D) number of leaves per plant; E) survival rate; F) dry mass of root; G) dry mass of shoot.

A

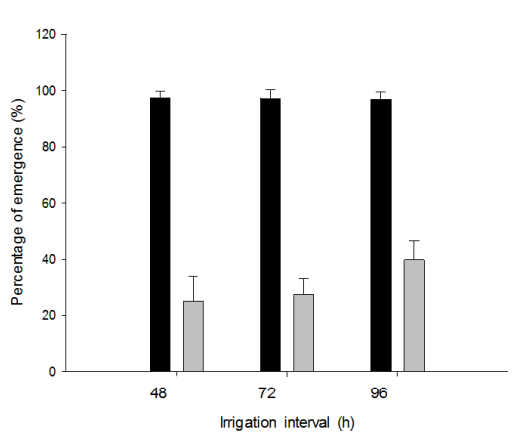

$\mathrm{C}$

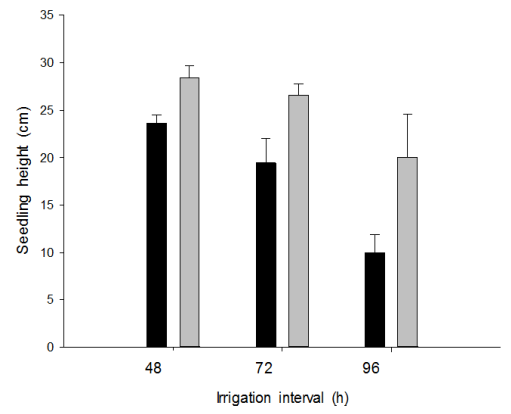

$\mathbf{E}$

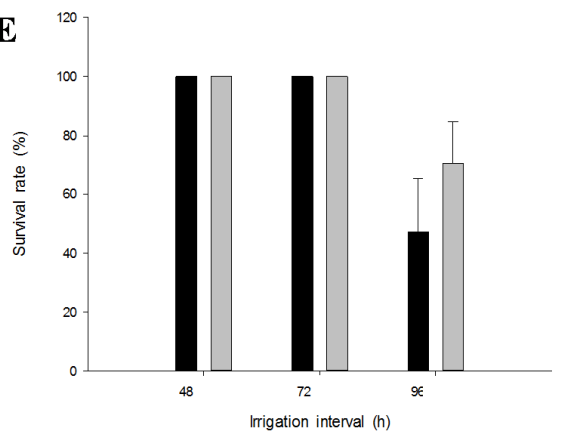

G

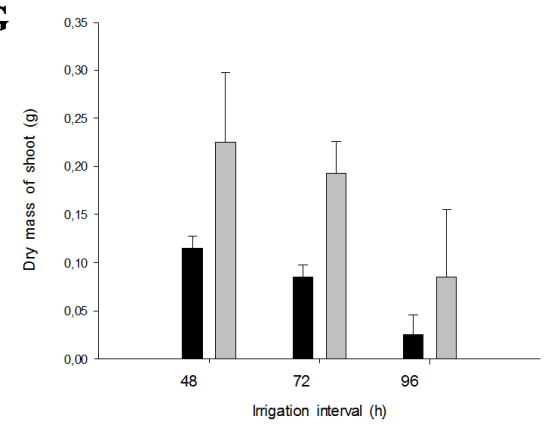

B

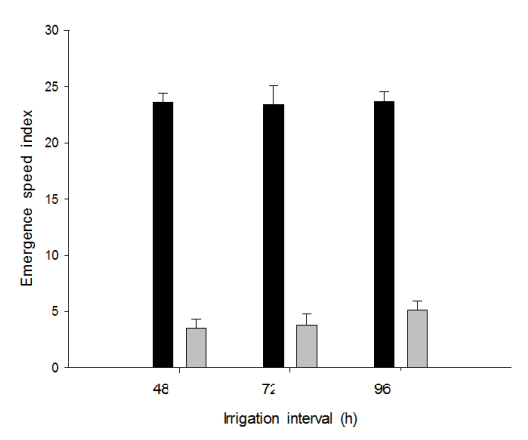

D
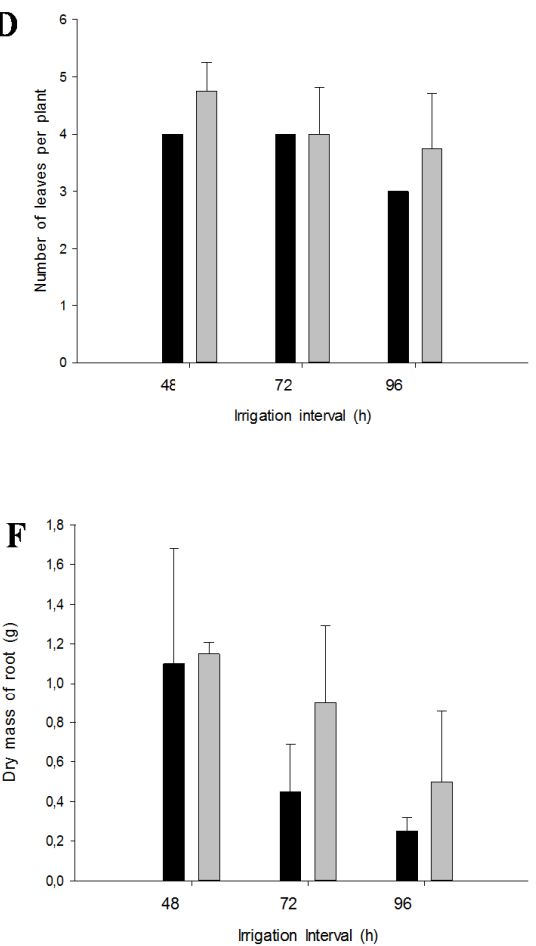
Figure 4. Regression model adjusted according to the irrigation interval (48, 72, 96 e 120 hours) and the method of using SAP (without SAP or control, seeds coated with SAP and SAP applied in the planting groove) for: A) plant height; B) number of leaves; C) leaf dry mass e D) stem dry mass.
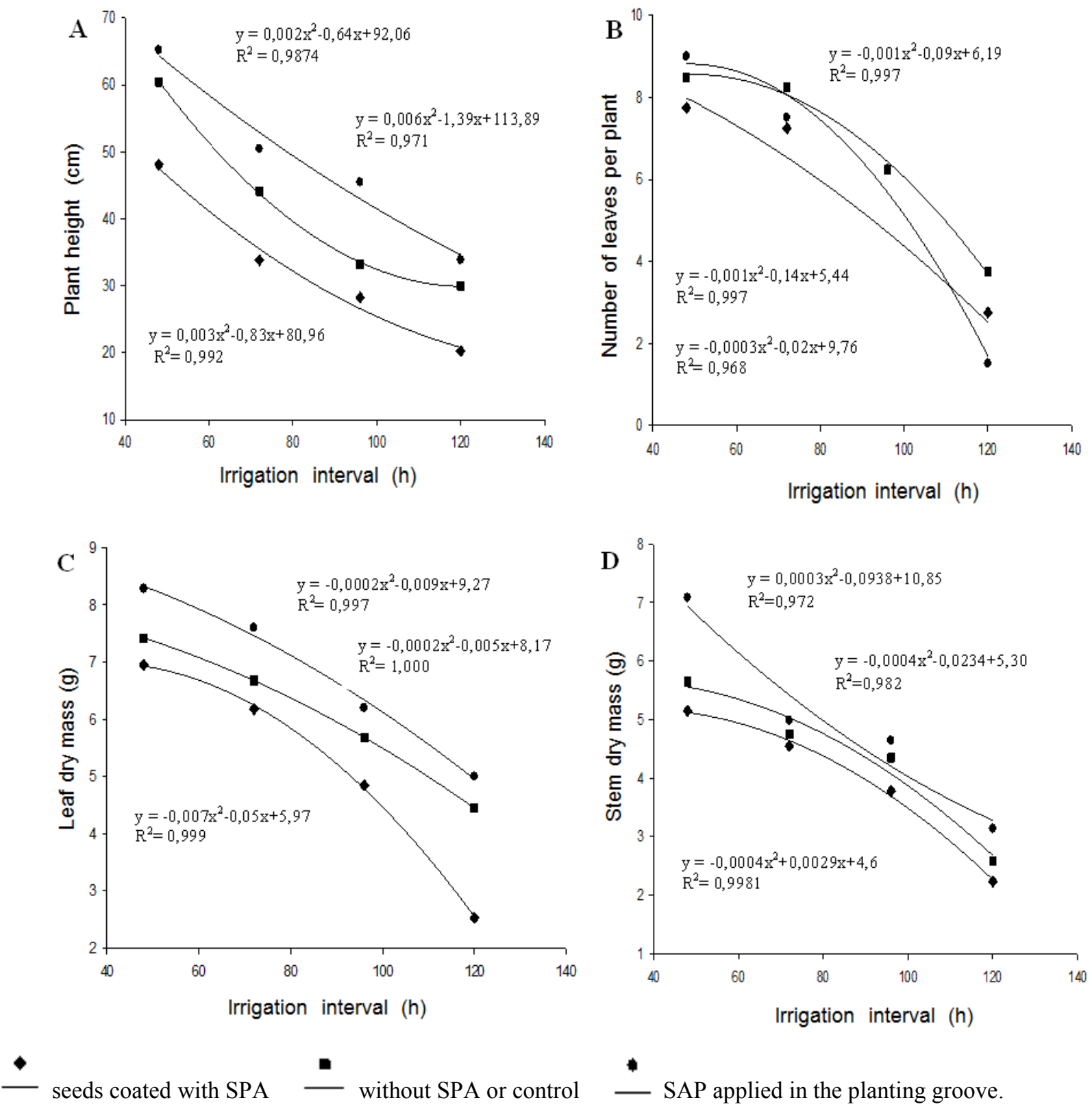

- SAP applied in the planting groove.

Table 3. Comparison of means between emergence speed index (ESI), seedling height (SH), leaf number (LN), survival rate (SR), dry mass root (DMR) and shoot (DMS) in sorghum seedlings at 26 days as a function of seed coating with superabsorbent polymer (SAP).

\begin{tabular}{lcccccc}
\hline Treatment & ESI & SH $(\mathrm{cm})$ & LN & SR (\%) & DMR $(\mathrm{g})$ & DMS $(\mathrm{g})$ \\
\hline Without SAP & $23.57 \mathrm{a}$ & $18.11 \mathrm{~b}$ & $3.70 \mathrm{a}$ & $78.46 \mathrm{~b}$ & $0.63 \mathrm{a}$ & $0.08 \mathrm{~b}$ \\
SAP & $4.14 \mathrm{~b}$ & $25.24 \mathrm{a}$ & $4.19 \mathrm{a}$ & $90.26 \mathrm{a}$ & $0.88 \mathrm{a}$ & $0.17 \mathrm{a}$ \\
\hline
\end{tabular}

Means followed by the same letter in the column do not differ by Tukey's test at the 5\% probability level. 
In both Experiment 1 (Table 4) and Experiment 2 (Table 5), fewer plants were observed when SAP was applied to the seed. This effect was also found by Pazderu and Koudela (2013), who compared the effect of the use of SAP application as a solution (at three levels of concentration) on the germination of vegetable seeds. The authors attributed this effect to the fact that SAP can reduce the speed of water absorption of seeds, resulting in slower germination.
Indeed, in our experiments, SAP was applied in dry form, which may have induced water competition between the polymer and the seed during the initial soaking phase. The low emergence of the SAP - coated seeds may also have been aggravated by the reduced size of the sorghum seed (which is associated with less food reserve for seedling establishment). In this species, germination occurs from day 4, after seed imbibition, and the first leaf emerges at about day 7 (PINHO et al., 2014).

Table 4. Comparison of emergence means (\%) of seedlings as a function of superabsorbent polymer (SAP) coating for three irrigation intervals.

\begin{tabular}{lcc}
\hline \multirow{2}{*}{ Treatment } & \multicolumn{2}{c}{ Seed coating } \\
\cline { 2 - 3 } & Without SAP & $\mathrm{SAP}$ \\
\hline Irrigation 1 & $97.50 \mathrm{Aa}$ & $25.00 \mathrm{Bb}$ \\
Irrigation 2 & $97.25 \mathrm{Aa}$ & $27.50 \mathrm{Bb}$ \\
Irrigation 3 & $97.00 \mathrm{Aa}$ & $39.75 \mathrm{Ab}$ \\
\hline
\end{tabular}

Means followed by the same letter in the column do not differ by Tukey's test at the 5\% probability level.

Table 5. Average number of sorghum plants according to the method of use of SAP.

\begin{tabular}{lc}
\hline Method of application & NP \\
\hline Without SAP & $2.13 \mathrm{a}$ \\
Seeds coated & $1.06 \mathrm{~b}$ \\
SAP applied in the planting groove & $2.44 \mathrm{a}$ \\
\hline
\end{tabular}

Means followed by the same letter in the column do not differ by Tukey's test at the $5 \%$ probability level.

Alves and Teixeira (2012) studied the effect of different concentrations of hydrophilic gel application on the germination of tingui and cucumber seeds, and they observed that the intermediate dose of the gel increased the percentage of germination, while the higher dose reduced it. The same authors stated that the gel could absorb part of the water destined for the embryo. Therefore, it is necessary to adjust a dose of the SAP to ensure high seed germination efficiency. In our studies, the SAP dose used is recommended for the production of tree seedlings, and is probably a high dose for sorghum seeds, which may have resulted in reduced germination efficiency. Thus, it is of utmost importance that different SAP doses and polymer types are studied for seed coating. Hotta et al. (2014) evaluated the use of carrageenan-based SAP in the seed coat and obtained satisfactory germination, in addition to the improved growth in low water and nutrient availability conditions.

Comparison of the method of application of SAP by seed coating with the application in the planting groove and the control, as assessed in Experiment 2, showed that the latter resulted in increased plant height, leaf dry matter, and shoot dry matter, with the former reducing these variables compared to the control treatment. These results corroborate those of Azevedo et al. (2002), Lopes et al. (2010) and Jamnická et al. (2013) who showed that SAP improves the vegetative development of plants under conditions of water deficit. We note that it 
may also be necessary to develop a seed specific polymer in order to improve the germination process, in the view that both the variations in polymer granulometry and polymer application method (e.g., binder or layer application) could affect the interaction of SAP with seed. Further studies are needed to investigate specific polymers for use as seed coat during planting.

\section{Conclusions}

The use of SAP application in sorghum seeds, and likely in other annual crops, improves seedling vegetative development and survival rate under water deficit. Further work is needed to reduce the problem of low seed emergence when SAP is applied as a seed coat.

\section{Acknowledgements}

Thanks to CAPES, CNPq and FAPEMIG for the scholarships granted to the master's students and to the scientific initiation of the UFV Sorghum Program.

\section{References}

AHMED, E. M. Hydrogel: preparation, characterization, and applications: a review. Journal of Advanced Research, v. 6, n. 2, p. 105-121, 2015.

ALVES, M. C.; TEIXEIRA, A. Z. A. The effect of hydrophilic gel from the second layer of Tingui (Magonia pubescens St. Hil.) seeds on germination and early development of cucumber (Cucumis sativus L.). Estudos de Biologia - Ambiente e Diversidade, Curitiba, v. 34, n. 82, p. 61- 66, 2012.

AZEVEDO, T. L. F.; BERTONHA, A.; GONÇALVES, A. C. A. Uso de hidrogel na agricultura. Revista do Programa de Ciências Agro-Ambientais, Alta Floresta, v. 1, n. 1, p. 23-31, 2002.

BERNARDI, M. R.; SPEROTTO JUNIOR, M.; DANIEL, O.; VITORINO, A. C. T. Crescimento de mudas de Corymbia citriodora em função do uso de hidrogel e adubação. Cerne, Lavras, v. 18, n. 1, p. 67-74, 2012.
BORTOLIN, A.; AOUADA, F. A.; LONGO, E.; MATTOSO, L. H. Investigação do processo de absorção de água de hidrogéis de polissacarídeo: efeito da carga iônica, presença de sais, concentrações de monômero e polissacarídeo. Polímeros, São Carlos, v. 22, n. 2, p. 311$317,2012$.

BORGHI, E.; BORTOLON, L.; AVANZI, J. C.; BORTOLON, E. S. O.; UMMUS, M. E.; GONTIJO NETO, M. M.; COSTA, R. V. Desafios das novas fronteiras agrícolas de produção de milho e sorgo no Brasil - desafios da Região do MATOPIBA. In: KARAM, D.; MAGALHÃES, P. C. (Ed.). Eficiência nas cadeias produtivas e o abastecimento global. Sete Lagoas: Associação Brasileira de Milho e Sorgo, 2014. cap. 25, p. 263-278. Disponível em: <file:///C:/Users/ WINDOWS\%207/Downloads/Desafios-novas.pdf.>. Acesso em: 10 jun. 2015.

BRASIL. Ministério da Agricultura, Pecuária e Abastecimento. Regras para análise de sementes. Brasília: Mapa/ACS, 2009. 399 p.

DRANSKI, J. A. L.; JUNIOR, A. S. P.; CAMPAGNOLO, M.; MALAVAS, U. C. I.; MALAVAS, M. M. Sobrevivência e crescimento do pinhão-manso em função do método de aplicação e formulações de PSA. Revista Brasileira de Engenharia Agrícola e Ambiental, Campina Grande, v. 17, n. 5, p. 537-542, 2013.

FAGUNDES, M. C. P.; CAMILO, S. S.; SOARES, B. C.; LANA, I.; CRUZ, B.; MOREIRA, R. A. Hydrogel polymer in emergency and early growth of citrus rootstocks. African Journal of Agricultural Research, South Africa, v. 9, n. 35, p. 2681-2686, 2014.

GILBERT, N. How to avert a global water crisis. Nature, 2010. Disponível em: <http://palgrave.nature.com/ nature/archive/subject.html? code $=453 \&$ year $=2010 \&$ mo nth $=10 \&$ page $=3>$. Acesso em: 9 jun. 2015.

HOTTA, M.; JAMES KENNEDY, J.; HIGGINBOTHAM, C.; MORRIS, N. Synthesis and characterisation of novel l-carrageenan hydrogel blends for agricultural seed coating application. In: Applied mechanics and materials. China: Trans Tech Publications, 679, 2014. p. 81-91.

JAMNICKÁ, G.; DITMAROVÁ, L.; KURJAK, D. J.; KMET, J.; PSIDOVÁ, E.; MACKOVÁ, M.; GÖMÖRY, D.; STŘELCOVÁ, K. The soil hydrogel improved photosynthetic performance of beech seedlings treated under drought. Plant Soil Environ, Czech Republic, v. 59, n. 10, p.446-451, 2013.

LIU, F.; M. A. H.; XING, S.; DU, Z.; MA, B. Effects of super-absorbent polymer ondry matter accumulation and nutrient uptake of Pinus pinaster container seedlings. Journal of Forest Research, v. 18, n. 3, p. 220-227, 2013. 
LOPES, J. L. W.; SILVA, M. R.; SAAD, J. C. C.; ANGELICO, T. S. Uso de PSA na sobrevivência de mudas de Eucalyptus urograndis produzidas com diferentes substratos e manejos hídricos. Ciência Florestal, Santa Maria, v. 20, n. 2, p. 217-224, 2010.

MAGUIRE, J. D. Speeds of germination-aid selection and evaluation for seedling emergence and vigor. Crop Science, Madison, v. 2, n. 2, p. 176-177, 1962.

MARQUES, P. A. A.; BASTOS, R. O. B. Uso de diferentes doses de hidrigel para produção de mudas de pimentão. Applied Research \& Agrotechnology, Guarapuava, v. 3, n. 2, p. 53-57, 2010.

MENDONÇA, T. G.; URBANO, V. R.; PERES, J. G.; SOUZA, C. F. Hidrogel como alternativa no aumento da capacidade de armazenamento de água no solo. Water Resources and Irrigation Management, Cruz das Almas, v. 2, n. 2, p. 87-92, 2013.

MUELLER, N.; GERBER, J. S.; JOHNSTONM RAY, D. K.; RAMANKUTTY, N.; FOLEY, J. Closing yield gaps through nutrient and water management. Nature, n. 490 , p. $254-257$, 2012. Disponível em: <http://www. nature.com/nature/journal/v490/n7419/full/nature11420. html>. Acesso: 9 jun. 2015

NAVROSKI, M. C.; ARAUJO, M. M.; FIOR, C. S.; CUNHA, F. S.; BERGHETTI, A. L. P.; PEREIRA, M. O. Uso de hidrogel possibilita redução da irrigação e melhora o crescimento inicial de mudas de Eucalyptus dunnii Maiden. Scientia Foretalis, Piracicaba, v. 43, n. 106, p. 467-476, 2015.

NIMAH, N. M.; RYAN, J.; CHAUDHRY, M. A. Effect of synthetic conditioners on soil water retention, hydraulic conductivity, porosity, and agregation. Soil Science Society of America Journal, Madison, v. 47, n. 4, p. 742745, 1983.

ORIKIRIZA, L. J. B.; AGABA, H.; EILU, G.; KABASA, J. D.; WORBES, M.; HÜTTERMANN, A. Effects of hydrogels on tree seedling performance in temperate soils before and after water stress. Journal of Environmental Protection, Florida, v. 4, n. 7, p.1-9, 2013.
PAULINO, J.; FOLEGATTI, M. V.; SÁNCHEZROMÁN, R. M.; JOSÉ, J. V. Situação da agricultura irrigada no Brasil de acordo com o censo agropecuário 2006. Irriga, Botucatu, v. 16, n. 2, p. 163-176, 2011.

PAZDERU, K.; KOUDELA, M. Influence of hydrogel on germination of lettuce and onion seed at different moisture levels. Acta Universitatis Agricultura e et Silvicultura e Mendeliana e Brunensis, Mendelu, v. 61, n. 6, p. 1817-1822, 2013.

PINHO, R. G.; FIORINI, I. V. A.; SANTOS, A. O. Botânica. In: BORÉM, A.; PIMENTEL, L.; PARRELA, R. Sorgo: do plantio á colheita. Viçosa, MG: Ed. UFV, 2014.

R DEVELOPMENT CORE TEAM. R: a language and environment for statistical computing. Vienna: $\mathrm{R}$ Foundation for Statistical Computing, 2014. Disponível em: <http://www.R-project.org/>. Acesso em: 20 dez. 2014.

SAAD, J. C. C.; LOPES, J. L. W.; SANTOS, T. Manejo hídrico em viveiro e uso de hidrogel na sobrevivência pós-plantio de Eucalyptus urograndis em dois solos diferentes. Engenharia Agrícola, Jaboticabal, v. 29, n. 3, p. 404-411, 2009.

STRECK, N. A.; ALBERTO, C. M. Estudo numérico do impacto da mudança climática sobre o rendimento de trigo, soja e milho. Pesquisa Agropecuária Brasileira, Brasília, v. 41, n. 9, p. 1351-1359, 2006.

TAIZ, L.; ZEIGER, E. Fisiologia vegetal. 5. ed. Porto Alegre: Artmed, 2013. 954 p.

USDA World Agricultural Production. Circular Series WAP, Foreign Agricultural Service, 2016. 29 p. Disponível em: <http://apps.fas.usda.gov/psdonline/ circulars/production.pdf>. Acesso: 22 maio 2016.

VALE, G. F. R.; CARVALHO, S. P.; PAIVA, L. C. Avaliação da eficiência de polímeros hidroretentores no desenvolvimento do cafeeiro em pós-plantio. Coffee Science, Lavras, v. 1, n. 1, p. 7-13, 2006.

WALLACE, A.; WALLACE, G. A. Effect of polymer soil conditioners on emergence of tomato seedlings. Soil Science, Philadelphia, v. 141, n. 5, p. 321-323, 1986. 